\title{
Swiss democracy has its advantages
}

Sir - Swiss democracy clearly differs from both the British parliamentary model and the American system, in which the maximization of individual ends is constitutionally entrenched.

Contrary to your comments about the forthcoming referendum on 7 June on the proposed ban on the production and distribution of transgenic animals, field trials with genetically modified organisms and the patenting of genetically modified animals and plants (Nature 392, 741; 1998), there has indeed been wide public debate in Switzerland.

The potential benefits and risks have been discussed in widely read newspapers. There have also been the demonstrations, advertisements and campaigning that accompany any public vote.

Universities and research and technical institutes have held open days where citizens have come to see at first hand what molecular biology, genetic engineering and biotechnology represent. Municipalities have invited experts - predominantly scientists opposed to the ban - to lecture at community meetings. The 'No' side has been organized and provided with information. We cannot agree, therefore, that "few can have detailed knowledge of the issues at stake".

The government, lobbying groups and international organizations clearly have opinions about the issues under debate. Both sides have presented their views and permitted a public evaluation. As you admit, there is a risk, as is not unknown in political or scientific arenas. But Swiss democracy is one where 'microindicators' at the individual or community level complement macroscopic indicators, such as per capita gross domestic product (GDP).

The passing of the initiative may have a long-term negative effect on these macroindicators. But it may also be that the factors that measure quality of life for many of the population - such as the ability of rural inhabitants to practise traditional living, access to education and distribution of wealth - remain unaffected. There are strong advantages in the way in which the Swiss have, for the past several centuries, managed their democracy.

One argument that can be made against participative democracy is that the public may not be able to assess the effects on macroindicators such as GDP. But the argument in favour of referendums is that national and international institutions or corporations - as well, in this case, as the scientific community - may not be qualified to judge the impact of an alternative on such indicators of quality of life. In the end, it comes down to a choice of values.

Swiss participative democracy values micro-based quality-of-life indicators as complementary to macroeconomic indices. We do not claim that this choice is better than that of other countries. However, our participative democracy is designed on the basis of this - perhaps uniquely Swiss preference. Whatever the results of the referendum, "the appropriateness of decision-making by referendum in a highly complex world" is consistent with Swiss priorities. To judge it according to other democratic standards, regardless of how widely they are accepted internationally, is to ignore national autonomy, and all the consequences such choices imply.

\section{John C. Badoux}

(President)

David Hunkeler

Laboratory of Polymers and Biomaterials, Ecole Polytechnique Fédérale de Lausanne, CH-1015 Lausanne, Switzerland e-mail:jean-claude.badoux@pres.adm.epfl.ch hunkeler@igc.dc.epfl.ch

Sir - In the coming vote on a new article in the Swiss constitution on issues of gene technology for non-humans, the result will be decided by the votes of a majority of the population only in combination with the votes of the majority of cantons. If the proposed ban is to take effect, more than half of the citizens and more than half of the 26 cantons would have to accept it. It is rare in Swiss history for such a constitutional referendum to be passed.

Second, the Swiss population is capable of judging complex questions, even in a scientific context. The vote on nuclear energy eight years ago denied a ban on nuclear plants and approved a ten-year moratorium on building new facilities. In the coming vote, the Swiss population has no moderate alternative to approve. Several groups in parliament have suggested alternatives, but industry in particular has lobbied successfully against them. The legislation that the government offered instead is scattered in nine different laws, and is therefore not transparent for people and not easily controlled.

Third, promoters of the ban have raised around SwFr5 million (US\$3.4 million) for their campaign, whereas its opponents have a budget of SwFr35 million. Both sides use posters and slogans and try to appeal to the emotions of citizens. Such campaigns are usual in Switzerland before votes with important implications.

So I do not believe that the Swiss democratic instruments are responsible for the difficult situation with the vote on genetic engineering. Even if parts of the population do not understand scientific matters, it is not a lack of knowledge or reflection that has created support for the ban. Scientists failed until recently to try to gain public trust. Policy-makers clearly underestimated the danger of not presenting a moderate alternative for the vote or a coherent law. A controversial technology has to be negotiated to get acceptance by the public - not only in Switzerland.

\section{Rosmarie Waldner}

Stuhlenstr. 23,

CH 8123 Ebmatingen, Switzerland

e-mail: rosmarie.waldner@tages-anzeiger.ch

Sir - I agree with your advice to the Swiss that passage of their constitutional amendment on aspects of biotechnology would be a serious error. Your further advice about their form of government, however, may well harm the interests of science.

If the Swiss, by referendum, approve these draconian limits, you argue that the blame should be apportioned in part to their system of government. The Swiss version of democracy, though by no means perfect, has been in place during an era when the Swiss have enjoyed levels of personal freedom, security and wealth that would be the envy of most of the world. A careful analysis of the consequences of direct democracy through referendums might show that it is, on balance, undesirable, but your leading article neither attempts nor cites any such analysis. Your position seems to be simpler: if a popular vote would lead to the wrong decision about something as complex as science, it should not be held.

Science is necessarily part of the political system; it is and must be bound by the laws of the countries in which it works. Those opposed to the Swiss biotechnology initiative should work hard to defeat it, not complain about the rules that made it possible. If, without violating fundamental human rights or international agreements, the Swiss choose to forgo much biotechnology, such a choice, though foolish, is theirs to make. By questioning the legitimacy of that choice, you only strengthen an existing view that science is unwilling to accept any outside control, no matter how democratically imposed. I doubt that this helps Swiss opponents of the initiative; I fear it may harm the interests of science throughout the world.

Henry T. Greely

Stanford Law School,

Stanford, California 94305-8610, USA

e-mail:hgreely@stanford.edu 